\title{
Analisis Senyawa Metabolit Sekunder Ekstrak Etanol dan Ekstrak Air Kulit Buah Naga Merah (Hylocereus polyrhizus)
}

\author{
Dida Fitri Lanisthi, Lizma Febrina, Muhammad Amir Masruhim \\ Laboratorium Penelitian dan Pengembangan FARMAKA TROPIS Fakultas Farmasi \\ Universitas Mulawarman, Samarinda, Kalimantan Timur \\ Email : didalanisthi@yahoo.com
}

\begin{abstract}
ABSTRAK
Kulit buah naga merah telah banyak digunakan sebagai obat tradisional, berdasarkan data empiris masyarakat menggunakan kulit buah naga sebagai obat untuk diabetes, pelentur pembuluh darah, dan penyakit jantung dengan cara menyeduhnya dengan air kemudian airnya diminum. Sedangkan untuk mengolah kulit buah naga merah menjadi sebuah sediaan umumnya menggunakan pelarut etanol. Sehingga dilakukan pengujian untuk melihat kandungan senyawa metabolit sekunder pada ekstrak etanol kulit buah naga merah dan ekstrak air kulit buah naga merah. Skrining fitokimia merupakan suatu tahap seleksi awal untuk mendeteksi golongan senyawa kimia yang terdapat dalam ekstrak tumbuhan. Skrining fitokimia meliputi uji alkaloid, uji triterpenoid dan steroid, uji tanin, uji flavonoid dan uji saponin. Berdasarkan skrining fitokimia, ekstrak etanol kulit buah naga merah menunjukkan hasil positif pada uji alkaloid yakni pada pereaksi meyer dan dragendorff serta uji flavonoid. Ekstrak air kulit buah naga merah menunjukkan hasil positif pada uji alkaloid pada pereaksi dragendorff dan pada uji flavonoid.
\end{abstract}

Kata Kunci: kulit buah naga merah, fitokimia

\begin{abstract}
Red dragon fruit peel has been widely used as a traditional medicine, based on empirical data using the community as a dragon fruit peel to flex drugs including diabetes, blood vessels, and heart disease, by brewing with water and then drink the water. As for the red dragon fruit leather processing into a dosage generally using ethanol. Thus testing to see if they contain secondary metabolites in the ethanol extract red dragon fruit peel and aqueous extract of red dragon fruit peel. Phytochemical screening is an initial selection phase to detect a group of chemical compounds found in plant extracts. Phytochemical screening test include alkaloids, triterpenoids and steroids test, test tannins, flavonoids test and test saponins. Based on phytochemical screening, ethanol extract red dragon fruit peel showed positive results in a test of alkaloids that the meyer and dragendorff reagent and test flavonoids. Water extract of the red dragon fruit peel showed positive results in a test of alkaloids in dragendorff reagent and the test flavonoids.
\end{abstract}

Keywords: red dragon fruit peel, phytochemicals

\section{PENDAHULUAN}

Buah naga merupakan buah tropis yang banyak digemari oleh masyarakat karena memiliki khasiat dan manfaat serta nilai gizi cukup tinggi. Bagian dari buah naga merah 
30-35\% merupakan kulit buah naga merah namun seringkali hanya dibuang sebagai sampah.

Kulit buah naga merah memiliki kandungan nutrisi seperti karbohidrat, lemak, protein dan serat pangan. Kandungan serat pangan yang terdapat dalam kulit buah naga merah sekitar 46,7\% (Saneto, 2005). Kandungan serat kulit buah naga merah lebih tinggi dibandingkan dengan buah pear, buah orange dan buah persik (Saneto, 2005). Menurut Santoso (2011) serat pangan memiliki manfaat bagi kesehatan yaitu mengontrol berat badan atau kegemukan, menanggulangi penyakit diabetes, mencegah gangguan gastrointestinal, kanker kolon (usus besar) serta mengurangi tingkat kolestrol darah. Kulit buah naga merah telah banyak digunakan sebagai obat tradisional, berdasarkan data empiris masyarakat menggunakan kulit buah naga sebagai obat untuk diabetes, pelentur pembuluh darah, dan penyakit jantung dengan cara menyeduhnya dengan air kemudian airnya diminum. Oleh sebab itu, peneliti tertarik untuk mengetahui senyawa-senyawa metabolit sekunder yang terkandung dalam kulit buah naga merah. Namun, belum ada data ilmiah mengenai kandungan metabolit sekunder pada kulit buah naga merah.

\section{METODE PENELITIAN}

\section{Bahan}

Bahan yang digunakan dalam penelitian ini adalah kulit buah naga merah, $\mathrm{HCl} \mathrm{0,1}$ $\mathrm{N}$, aquades, $\mathrm{FeCl} 31 \%$, pereaksi dragendroff, pereaksi meyer, bubuk magnesium

\section{Peralatan}

Alat yang digunakan dalam penelitian ini adalah alat gelas, alat kaca, kertas saring, batang pengaduk, cawan porselin, hot plate, timbangan analitik, mikropipet $100-1000$ $\mu \mathrm{L}$, pipet tetes, tabung reaksi, rak tabung, rotary evaporator, dan oven.

\section{Prosedur}

\section{Penyiapan Sampel dan Ekstrak}

Penyiapan ekstrak dilakukan dengan cara membersihkan kulit buah naga merah (Hylocereus polyrhizus) dari pengotornya kemudian dipotong kecil-kecil lalu dikeringkan menggunakan oven dan dimaserasi dengan menggunakan pelarut etanol, Dilakukan perlakuan yang sama terhadap pelarut air kemudian diuapkan pelarutnya dengan rotary evaporator. Setelah itu ekstrak etanol diuapkan di atas waterbath hingga menjadi ekstrak kental, sedangkan ekstrak air dilakukan freeze drying.

\section{Skrining Fitokimia}

\section{Uji Alkaloid}

Sebanyak $2 \mathrm{~mL}$ ekstrak diuapkan di atas cawan porselin. Residu yang dihasilkan kemudian dilarutkan dengan $5 \mathrm{~mL} \mathrm{HCl} 2 \mathrm{M}$. Larutan yang diperoleh dibagi ke dalam 3 tabung reaksi. Tabung pertama berfungsi sebagai blanko, ditambahkan dengan 3 tetes $\mathrm{HCl}$ 2 M. Tabung kedua ditambahkan 3 tetes pereaksi Dragendorff dan tabung ketiga ditambahkan 3 tetes pereaksi Mayer. Pada pereaksi Dragendorff akan terbentuk endapan berwarna jingga sedangkan pereaksi Mayer akan terbentuk endapan kuning yang menandakan positif adanya alkaloid (Farsnworth, 1966).

\section{Uji Flavonoid}

Sebanyak $2 \mathrm{~mL}$ ekstrak ditambahkan dengan air panas secukupnya, kemudian dididihkan selama 5 menit lalu disaring. Filtrat sebanyak $5 \mathrm{~mL}$ ditambahkan $0,05 \mathrm{mg}$ 
serbuk $\mathrm{Mg}$ dan $1 \mathrm{~mL} \mathrm{HCl}$ pekat, kemudian dikocok kuat-kuat. Uji positif ditunjukkan dengan terbentuknya warna merah, kuning atau jingga (Harborne, 1987).

\title{
Uji Tanin
}

Sebanyak $1 \mathrm{~mL}$ ekstrak ditambahkan dengan beberapa tetes larutan besi(III)klorida $10 \%$. Jika terjadi warna biru tua atau hitam kehijauan menunjukkan adanya tanin (Jones dan Kinghorn, 2006; Robinson, 1995).

\section{Uji Steroid dan Triterpenoid}

Sebanyak $2 \mathrm{~mL}$ ekstrak ditambahkan $\mathrm{CH}_{3} \mathrm{COOH}$ glasial sebanyak 10 tetes dan $\mathrm{H}_{2} \mathrm{SO}_{4}$ pekat sebanyak 2 tetes. Larutan dikocok perlahan dan dibiarkan selama beberapa menit. Adanya steroid ditunjukan oleh warna biru atau hijau, sedangkan triterpenoid memberikan warna merah atau ungu (Harborne, 1987).

\section{Uji Saponin}

Sebanyak 2-3 mL ekstrak dimasukkan ke dalam tabung reaksi, kemudian ditambahkan $10 \mathrm{~mL}$ air panas lalu didinginkan, kemudian dikocok kuat-kuat selama 10 detik lalu ditambahkan 1 tetes $\mathrm{HCl} 2 \mathrm{~N}$. Uji positif ditunjukkan dengan terbentuknya buih yang stabil setinggi 1-10 cm selama tidak kurang dari 10 menit (Depkes RI, 1995)

\section{HASIL DAN PEMBAHASAN}

Hasil skrining fitokimia menunjukan bahwa ekstrak etanol dan ekstrak air kulit buah naga merah memiliki kandungan senyawa metabolit sekunder yang sama yaitu positif terdapat senyawa alkaloid dan flavonoid

Tabel 1 menunjukan hasil skrining fitokimia terhadap ekstrak etanol kulit buah naga merah.

\begin{tabular}{llcc}
\hline & Uji & \multicolumn{2}{c}{ Hasil } \\
\cline { 2 - 4 } & & EE & EA \\
\hline Alkaloid & Meyer & + & - \\
& Dragendorff & + & + \\
Saponin & & - & - \\
Flavonoid & + & + \\
steroid & - & - \\
terpenoid & - & - \\
tanin & & - & - \\
\hline
\end{tabular}

Keterangan :

$(-)=$ senyawa tidak terdeteksi, $(+)=$ senyawa terdeteksi, $(\mathrm{EE})=$ Ekstrak Etanol kulit buah naga merah, $(\mathrm{EA})=$ Ekstrak Air kulit buah naga merah

\begin{abstract}
Alkaloid
Alkaloid yang diuji dengan menggunakan pereaksi Dragendorff akan menghasilkan endapan berwarna jingga, sedangkan dengan pereaksi Mayer akan menghasilkan endapan berwarna putih kekuningan, penambahan asam klorida bertujuan untuk mengekstrak alkaloid yang bersifat basa dengan menggunakan larutan asam (Farnsworth, 1966; Jones dan Kinghorn, 2006). Hasil skrining fitokimia menunjukan adanya endapan, yang berarti bahwa ekstrak etanol kulit buah naga merah terdapat senyawa alkaloid.sedangkan ekstrak
\end{abstract}


air kulit buah naga merah hanya menghasilkan endapan pada pereaksi dragendorff yang berarti positif alkaloid.

\section{Flavonoid}

Flavonoid dapat diuji keberadaannya menggunakan $\mathrm{Mg}$ dan $\mathrm{HCl}$ pekat. Senyawa flavonoid dapat menghasilkan warna merah, kuning atau jingga ketika tereduksi dengan $\mathrm{Mg}$ dan $\mathrm{HCl}$ (Harborne, 1987). Hasil skrining fitokimia menunjukan ekstrak etanol kulit buah naga merah berwarna kuning dan berawarna merah muda pada ekstrak air kulit buah naga merah dan positif terdapat flavonoid. Beragam warna yang dihasilkan ketika pengujian, dipengaruhi oleh pelarut dan prosedur yang digunakan (Sangi et al., 2008).

\section{Tanin}

Identifikasi terhadap senyawa tanin dilakukan melalui penambahan $\mathrm{FeCl} 3$. Senyawa tanin adalah senyawa yang bersifat polar karena adanya gugus $\mathrm{OH}$, ketika ditambahkan $\mathrm{FeCl} 3$ 10\% akan terjadi perbahan warna seperti biru tua atau hijau kehitaman yang menandakan adanya senyawa tanin (Jones dan Kinghorn, 2006; Robinson, 1991).

Menurut Sangi et al. (2008), tanin terhidrolisis akan menunjukan warna biru kehitaman sedangkan tanin terkondensasi akan menunjukan warna hijau kehitaman ketika penambahan $\mathrm{FeCl} 3$. Dari hasil skrining fitokimia pada ekstrak etanol dan ekstrak air kulit buah naga merah diperoleh hasil warna kuning yang berarti tidak terdapat senyawa tanin.

\section{Steroid Dan Triterpenoid}

Pengujian steroid dan triterpenoid dalam $\mathrm{CH} 3 \mathrm{COOH}$ glasial dengan $\mathrm{H} 2 \mathrm{SO} 4$ pekat didasarkan pada kemampuan senyawa steroid dan triterpenoid dalam membentuk warna biru atau hijau untuk steroid, dan merah atau ungu untuk triterpenoid. Steroid dan triterpenoid merupakan senyawa yang dapat terekstraksi dengan pelarut non polar atau semi polar (Harborne, 1987; Nurjanah, 2011).

Hasil skrining fitokimia menunjukan ekstrak etanol dan ekstrak air kulit buah naga merah memberikan warna merah muda yang berarti tidak terdapat senyawa steroid dan terpenoid.

\section{Saponin}

Saponin merupakan senyawa aktif permukaan yang mudah terdeteksi melalui kemampuannya dalam membentuk busa. Komponen ikatan glikosida yang terdapat didalam saponin menyebabkan senyawa ini cenderung bersifat polar (Harborne, 1987; Sangi et al., 2008). Keberadaan saponin positif jika ekstrak yang diuji membentuk busa setinggi $1-10 \mathrm{~cm}$ dengan selang waktu \pm 10 menit (Depkes RI, 1995). Berdasarkan hasil skrining fitokimia menunjukan ekstrak etanol dan ekstrak kulit buah naga merah tidak terdapat saponin karena tidak membentuk busa.

\section{KESIMPULAN}

Analisis senyawa metabolit sekunder pada ekstrak etanol dan ekstrak air kulit buah naga merah positif terdapat senyawa alkaloid dan flavonoid.

\section{Daftar Pustaka}

1. Depkes RI. 1995. Farmakope Indonesia. Departemen Kesehatan Republik Indonesia, Jakarta.

2. Farsnworth, N. R. 1966. Biological and Phytochemical Screening of Plant. Journal of Pharmaceutical Sciences. 55: 59.

3. Harborne, J.B. 1987. Metode Fitokimia. Terjemahan: Padmawinata, K dan Soediro, I. Institut Teknologi Bandung, Bandung. 
4. Jones, W.P., Kinghorn, A.D. 2006. Extraction of Plant Secondary Metabolites. In: Sharker, S.D. Latif Z., Gray A.L, eds. Natural Product Isolation. 2nd edition. Humana Press. New Jersey.

5. Saneto, B. 2005. Karakterisasi kulit buah naga merah (Hylocereus polyrhizus.). Jurnal Agarika. Vol 2: 143- 149.

6. Santoso, A. 2011. Serat pangan (Dietary fiber) dan manfaatnya bagi kesehatan. Jurnal Magistra. Vol 2: 35-40.

7. Wahyuni, R. 2011. Pemanfaatan kulit buah naga super merah (Hylocereus costaricensis.) sebagai sumber antioksidan dan pewarna alami pada pembuatan jelly. Jurnal Teknologi Pangan. Vol 2: 68- 85 